MINERALOGIA, 39, No. 3-4: 87-103 (2008)

DOI: $10.2478 / v 10002-008-0007-3$

www.Mineralogia.pl

MINERALOGICAL SOCIETY OF POLAND

Original paper

\title{
Bi-Se-Te mineralization from Úhorná (Spišsko Gemerské Rudohorie Mts., Slovakia): A preliminary report
}

\author{
Jaroslav PRŠEK ${ }^{1 *}$, Dušan PETEREC ${ }^{2}$
}

\author{
1 Comenius University, Faculty of Natural Sciences, Department of Mineralogy and Petrology, \\ Mlynská dolina 842 15, Bratislava; e-mail: prsek@yahoo.com \\ 2 Aragonit s.r.o, Rovníková 8, 04012 Košice \\ * Corresponding author
}

Received: January 31, 2008

Accepted: January 07, 2009

\begin{abstract}
An unusual association of Se minerals was studied. Se enters into the structures of sulphosalts - into bournonite, jamesonite and tintinaite at concentrations up to 0.10, 0.38 and 1.11 apfu, respectively. However, Se and $\mathrm{Te}$, together with $\mathrm{Bi}$, also form discrete minerals such as tetradymite, laitakarite, ikunolite and hedleyite. Members of the laitakarite-ikunolite solid solution display a wide range of anion substitution from the nearly Se-free $(0.10$ apfu $)$ end member to the S-poor (0.42 apfu) end member. Their contents of Te are low. Accompanying tetrahedrite does not contain $\mathrm{Se}$ or Te.
\end{abstract}

Key-words: laitakarite-ikunolite solid solutions, sulphosalts, tetradymite, Slovakia, Úhorná

\section{Introduction}

In Slovakia, occurrences of Se- and Te minerals are relatively rare in comparison with other sulphide minerals. Besides occurrences in Neogene volcanites (neovolcanites), they have only been identified in a few localities. Tellurides of $\mathrm{Bi}, \mathrm{Au}$ and $\mathrm{Ag}$ occur in the neovolcanites. Tetradymite was described from Župkov, Hodruša, Bukovec and Kopanice (Zepharovich 1859, 1873; Lexa et al. 1989; Kalinaj, Bebej 1992; Mat'o, Bebej 1994; Jeleň 2003; Sejkora et al. 2004 and others), hessite from Kremnica, Šobov and Vyhne (Štohl et al. 1989; Mat'o et al. 1990; Mat'o 1994; Mat'o et al. 1996). Altaite, petzite, stützite, goldfieldite, benleonardite, tellurobismutite were described by Mat'o et al. (1987), Mat'o et al. (1990), Onačila et al. (1993), Mat'o 
(1994) and Mat'o et al. (1996) from Kremnica, and Vyhne. A review of the Te-Se mineralogy in the neovolcanic field of Central Slovakia is provided by Jeleň et al. (2004). An interesting association of Te minerals, including canfieldite, rickardite, sylvanite, altaite, weissite and cervelleite was described from Zlatá Baňa by Kaličiak and Ďud'a (1981), Ďud'a et al. (1981) and Ďud'a (1986). New minerals containing Bi and Te (vihorlatite and telluronevskite) were recently identified from Poruba pod Vihorlatom (Řídkošil et al. 2001, Skála et al. 2007). In addition to the neovolcanite occurrenes, tetradymite has been identified as a component of scheelite mineralization in the Dúbrava deposit by Chovan, Michálek (1988) and tetradymite, together with other Bi tellurides (joséite B, tsumoite, pilsenite, tellurobismuthite and tellurantimony), was identified in the Jasenie-Kyslá scheelite deposit by Beňka and Suchý (1983) and Bláha, Vitásek (1991). Tetradymite has also been described from Kokava nad Rimavicou (Zepharovich 1859, 1973) and from Katarínska Huta where it occurs together with tellurobismuthite (Ferenc 2004; Ferenc, Bakos 2006). An association of Bi tellurides and Bi sulphosalts, comprising joséite-A, joséite-B and baksanite, was recently described from Chyžné-Herichová (Bálintová, Ozdín 2006). Minerals, in which selenium dominates, are rare in the Western Carpathians. Up to now, they have been identified only at a few localities. Naumannite was described from Banská Štiavnica (Jeleň 1994), and clausthalite from Novoveská Huta (Rojkovič et al. 1993). Laitakarite and other selenium-rich sulphosalts were found in Hnúšt’a (Ragan, Caňo 1991) in association with tetradymite (Ragan 1989). More recently, tsumoite, hessite and pilsenite were identified in paragenesis with chalcopyrite (Ferenc 2004). High contents of $\mathrm{Bi}$, Se and Te in main sulphides from the Smolník volcanic-sedimentary massive sulphide deposit (Ilavský 1954) suggest the possible occurrence of Se-, Te- and Bi-bearing minerals in the sulphide veins in the deposit surroundings. Peterec $(1991,1996)$, following this suggestion, identified Se and Te minerals for the first time in vein mineralization at Úhorná near Smolník. He described Bi- and Se-bearing jamesonite, Se-bearing "horobetsuite", Se-bearing pekoite, Se- and Te-bearing galena and laitakarite, ikunolite and, questionably, ingodite. The present work contains detailed microprobe analyses of newly found Se-Te minerals as well as precise data for previously reported phases.

\section{Characterization of the locality}

Samples of the sulphide mineralization with Se and Te minerals were collected from dumps of the Šarlota-Eleonóra vein system. The NE-SW vein system runs through the Malá kotlina fold and the Kovandská dolina valley approximately $3 \mathrm{~km} \mathrm{SW}$ of Smolník (Fig. 1). The ore veins are hosted in porphyroids and phyllites of the Gelnica series (Grecula et al. 1995). The veins are relatively short $(<300 \mathrm{~m})$ with a maximum thickness of $1 \mathrm{~m}$. They have never been exploited for ore. Only prospecting and minor excavation works were undertaken from 1950-1955. The siderite-quartz-sulphide veins contain variable sulphide contents (Grecula et al. 1995).

The siderite veins with $\mathrm{Bi}, \mathrm{Te}, \mathrm{Se}, \mathrm{Co}$ and $\mathrm{Ni}$ minerals are linked to the volcanic-sedimentary massive sulphide deposits in the Smolník area (Grecula et al. 1995; Peterec 1991). Ilavský (1954) and Peterec (1991) considered that the veins developed during metamorphism of the surrounding rocks and that the ore elements were leached from the Smolník deposit. Grecula 


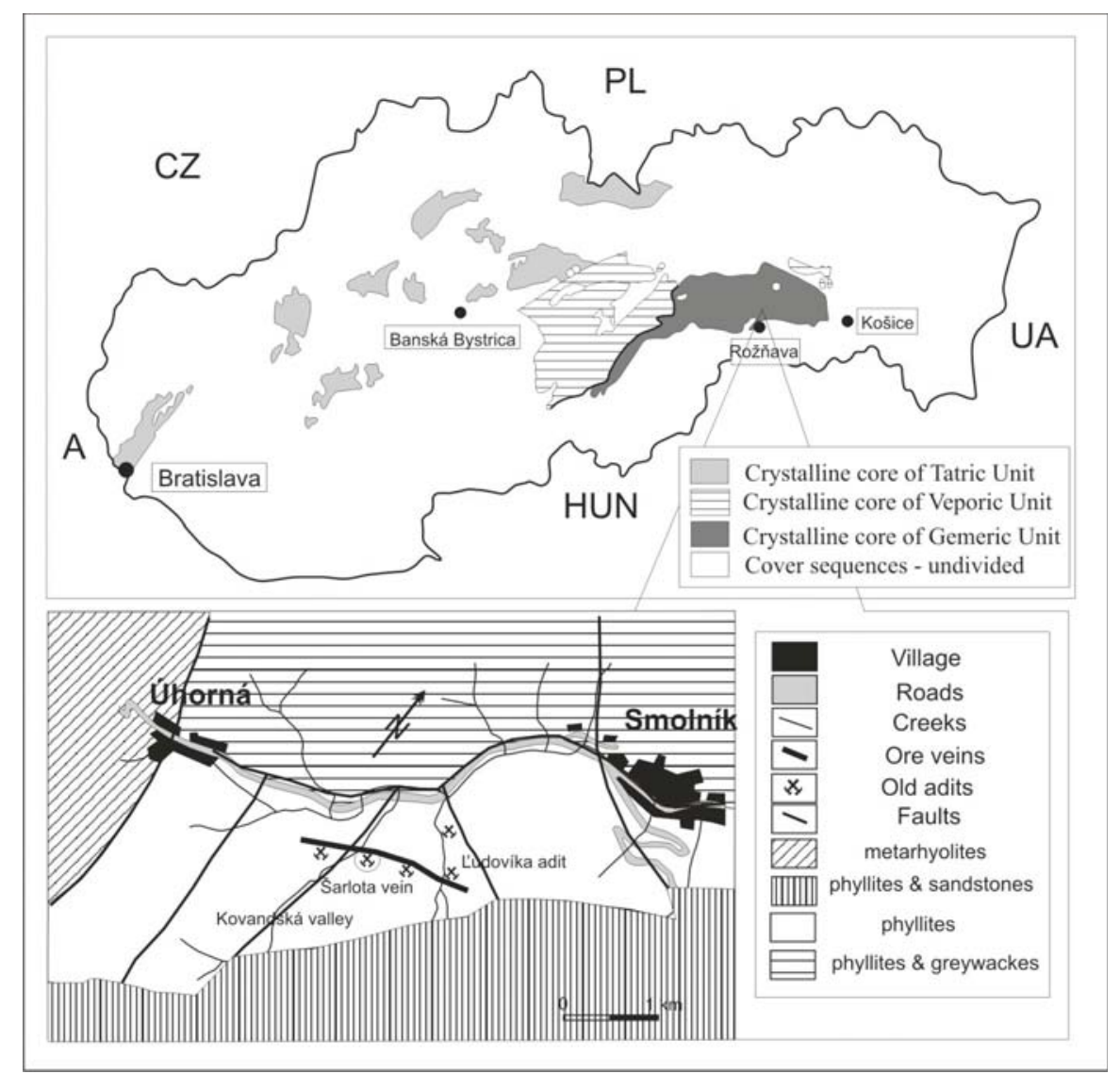

Fig. 1. Simple geological sketch of Slovakia showing the topographic and geological position of the locality studied

et al. (1995) and Radvanec et al. (2004) considered that the siderite veins formed during the Variscan orogeny (with Alpine overprint) and that the source of metals was the surrounding rocks. Hurai et al. (2002) dated the veins as Jurassic-Cretaceous and ascribed their origin to the mixing of marine brines, meteoric water and metamorphogenic fluids.

The veins are mainly filled with siderite and quartz. Sulphide contents reach up to several percents but are usually negligible. Chalcopyrite, pyrite, tetrahedrite, pyrrhotite, arsenopyrite, ullmanite, gersdorffite, galena and some $\mathrm{Pb}, \mathrm{Cu}, \mathrm{Fe}, \mathrm{Sb}, \mathrm{Bi}$ sulphosalts (e.g., jamesonite and kobellite) have been described (Grecula et al. 1995, Peterec 1996). Complex Pb-bearing sulphosalts together with tetrahedrite are deemed to be accumulators of residual elements at the end of the crystallization process. The Bi-Se-Te minerals commonly occur as inclusions and exsolutions in these sulphosalts. Jamesonite, the most common sulphosalt, usually forms needle-like crystals $<1 \mathrm{~cm}$ long and commonly contains minor amounts of Bi and Se (Peterec 1991, 1996). Te minerals and sulphosalts are found in samples with tetrahedrite. Of twenty polished sections of tetrahedrite bearing ore examined, Te minerals were found in only five though sulphosalts occurred in all. 


\section{Methods}

The chemical compositions of the sulphosalts and Bi-, Se- and Te phases were obtained using a Cameca SX 100 electron microprobe at the State Geological Institute of Dionýz Štúr, Bratislava. Operating conditions were as follows: accelerating voltage $20 \mathrm{kV}$, probe current $20 \mathrm{nA}$ and a beam diameter of $5 \mu \mathrm{m}$ for sulphosalts and, for the Bi-, Se and Te phases, an accelerating voltage $20 \mathrm{kV}$, probe current 10 and $20 \mathrm{nA}$ and a beam diameter of $1-5 \mu \mathrm{m}$. The following standards and spectral lines were used: pure $\mathrm{Ag}(\mathrm{AgL} \alpha)$, pure $\mathrm{Cd}(\mathrm{CdL} \alpha)$ and $\mathrm{Sb}$ $(\mathrm{SbL} \alpha)$, synthetic $\mathrm{PbS}(\mathrm{PbL} \alpha), \mathrm{Bi}_{2} \mathrm{~S}_{3}(\mathrm{BiL} \alpha), \mathrm{Bi}_{2} \mathrm{Se}_{3}(\mathrm{SeL} \beta)$ and $\mathrm{Bi}_{2} \mathrm{Te}_{3}(\mathrm{TeL} \alpha)$, natural $\mathrm{CuFeS}_{2}(\mathrm{CuK} \alpha, \mathrm{FeK} \alpha, \mathrm{SK} \alpha)$ and $\mathrm{ZnS}(\mathrm{ZnK} \alpha)$. The results were corrected using an on-line $\mathrm{ZAF}$ correction.

For tintinaite, the homologue number $(\mathrm{N})$ was obtained using the following calculation of Zakrzewski and Makovicky (1986): $N=x\left(6 M^{2+}+3 M^{3+}\right) /\left(4 M^{3+}-M^{2+}\right)+(1-x)\left(5 M^{2+}+\right.$ $\left.+2 M^{3+}\right) /\left(4 M^{3+}-M^{2+}\right)$, where $x=T^{+} /\left(T^{+}+T^{2+}\right),(1-x)=T^{2+} /\left(T^{+}+T^{2+}\right), T^{+}$is the content of the tetrahedrally coordinated monovalent cations $(\mathrm{Cu}), T^{2+}$ is the content of the tetrahedrally coordinated divalent cations $(\mathrm{Fe}), M^{2+}$ is the sum of divalent cations $(\mathrm{Pb}, \mathrm{Zn}, \mathrm{Cd})$ and $\mathrm{M}^{3+}$ is the sum of trivalent cations ( $\mathrm{Sb}, \mathrm{Bi}$ ). The content of silver was calculated using the lillianite type of substitution $\mathrm{Ag}+\mathrm{Bi}=2 \mathrm{~Pb}$.

\section{Results}

We studied the chemical composition of the common sulphosalts, the rare minerals containing $\mathrm{Bi}$, Se and $\mathrm{Te}$, and of the accompanying tetrahedrite. The Bi- Se- and Te minerals and Bi sulphosalts occur in association with tetrahedrite and chalcopyrite. Sulphosalts such as tintinaite, jamesonite and bournonite form mainly small $(<1-2 \mathrm{~mm})$ needle-like crystals in quartz, siderite and tetrahedrite. The Se-Te minerals occur as small $(<50 \mu \mathrm{m})$ platy or needle like crystals or as complex decomposition products enclosed in jamesonite and tetrahedrite. We have identified $\mathrm{Bi}$ - and Se-bearing jamesonite, Se-bearing tintinaite, Se-bearing bournonite, tetradymite, native bismuth, minerals of the laitakarite-ikunolite solid solution series, hedleyite and a phase chemically close to $\mathrm{X}_{3} \mathrm{~S}_{4}$, where $\mathrm{X}$ is $\mathrm{Bi}+\mathrm{Sb}+\mathrm{Cu}$.

\subsection{Tetrahedrite}

Tetrahedrite is the most common sulphide in the material studied. It forms aggregates of allotriomorphic $<1 \mathrm{~cm}$ grains, and intergrowths with chalcopyrite embedded in quartz and siderite. In some cases, small needles of sulphosalts can be seen in the tetrahedrite. No zoning is evident in reflected light or in the BSE images; each grain appears to be chemically homogenous. Although it contains inclusions and decomposition products of $\mathrm{Bi}$ - Se- and $\mathrm{Te}$ minerals, no significant contents of Se and Te were detected by electron microprobe. Compositionally, the mineral is close to an end-member tetrahedrite with a small content of the tennantite molecule (4.5\%) and low trace element content (Table 1). Arsenic contents vary in the range $0.50-0.83 \mathrm{wt} \%$ and $\mathrm{Bi}$ content reaches a maximum of $0.54 \mathrm{wt} \%$. Moreover, $\mathrm{Ag}$ substitution for $\mathrm{Cu}$ is very low. The content of $\mathrm{Ag}$ ranges from $0.68-1.23 \mathrm{wt} \%$. The dominant 
TABLE 1

Electron microprobe analyses of tetrahedrite and crystallochemical formulas calculated on the basis of 16 cations

\begin{tabular}{|c|c|c|c|c|c|c|c|c|c|c|c|}
\hline Sample & $\mathrm{S}$ & $\mathrm{Cu}$ & $\mathrm{Sb}$ & $\mathrm{Hg}$ & $\mathrm{Ag}$ & As & $\mathrm{Fe}$ & $\mathrm{Zn}$ & $\mathrm{Cd}$ & $\mathrm{Bi}$ & Total \\
\hline \multicolumn{12}{|c|}{ Weight \% } \\
\hline Р 34 & 24.77 & 37.46 & 29.04 & 0.16 & 1.18 & 0.49 & 5.39 & 1.62 & 0.07 & 0.12 & 100.29 \\
\hline Р 34 & 24.92 & 37.43 & 28.11 & 0.14 & 1.12 & 0.67 & 5.55 & 1.63 & 0.07 & 0.52 & 100.15 \\
\hline P 34 & 24.92 & 36.99 & 28.49 & 0.17 & 1.14 & 0.70 & 5.08 & 2.02 & 0.05 & 0.30 & 99.90 \\
\hline P 34 & 24.76 & 37.25 & 28.45 & 0.10 & 1.12 & 0.83 & 5.07 & 2.04 & 0.04 & 0.14 & 99.79 \\
\hline UH-02 & 24.68 & 37.67 & 28.14 & n.d. & 0.68 & 0.82 & 5.18 & 1.82 & 0.05 & 0.19 & 99.23 \\
\hline $\mathrm{n}=9$ & 24.81 & 37.36 & 28.45 & 0.14 & 1.05 & 0.70 & 5.25 & 1.83 & 0.06 & 0.25 & 99.88 \\
\hline \multicolumn{12}{|c|}{ Formula* } \\
\hline Р 34 & 12.76 & 9.74 & 3.94 & 0.01 & 0.18 & 0.11 & 1.59 & 0.41 & 0.01 & 0.01 & \\
\hline P 34 & 12.86 & 9.74 & 3.82 & 0.01 & 0.17 & 0.15 & 1.64 & 0.41 & 0.01 & 0.04 & \\
\hline P 34 & 12.95 & 9.70 & 3.90 & 0.01 & 0.18 & 0.16 & 1.51 & 0.52 & 0.01 & 0.02 & \\
\hline Р 34 & 12.81 & 9.72 & 3.88 & 0.01 & 0.17 & 0.18 & 1.50 & 0.52 & 0.01 & 0.01 & \\
\hline UH-02 & 12.79 & 9.85 & 3.84 & n.d. & 0.10 & 0.18 & 1.54 & 0.46 & 0.01 & 0.02 & \\
\hline $\mathrm{n}=9$ & 12.77 & 9.76 & 3.85 & 0.01 & 0.17 & 0.15 & 1.57 & 0.45 & 0.01 & 0.02 & \\
\hline
\end{tabular}

* Based on $\Sigma$ cations $=16$, Te and Se are below detection limit, $\mathrm{n}=$ number of analyses used for mean composition calculation.

element in the divalent position is Fe with its content from 5.0-5.6 wt\% with zinc present in smaller amounts from $1.55-2.11 \mathrm{wt} \%$. The Cd content reaches $0.07 \mathrm{wt} \%$ and that of $\mathrm{Hg}$ $0.30 \mathrm{wt} \%$. The general formula of the tetrahedrite (calculated using a total of 16 cations) is $\left(\mathrm{Cu}_{9.76} \mathrm{Ag}_{0.17}\right)_{9.93}\left(\mathrm{Fe}_{1.57} \mathrm{Zn}_{0.45} \mathrm{Cd}_{0.01} \mathrm{Hg}_{0.01}\right)_{2.04}\left(\mathrm{Sb}_{3.85} \mathrm{As}_{0.15} \mathrm{Bi}_{0.02}\right)_{4.02} \mathrm{~S}_{12.77}$.

\subsection{Jamesonite}

Jamesonite is the most common sulphosalt. It needle-like crystals $(<1 \mathrm{~cm})$ are enclosed in quartz, siderite or most commonly in tetrahedrite. Jamesonite is usually intergrown with tintinaite and contains inclusions and decomposition products of the $\mathrm{Bi}-$, Se- and Te minerals (Fig. $2 \mathrm{~A}-\mathrm{C})$. It is commonly replaced by minerals of the bindheimite group $\left(\mathrm{A}_{2} \mathrm{X}_{2} \mathrm{O}_{6}\right)(\mathrm{O}, \mathrm{OH}, \mathrm{F})$, where $\mathrm{A}$ is usually $\mathrm{Pb}, \mathrm{Ca}, \mathrm{Cu}, \mathrm{Sb}, \mathrm{Fe}$ and $\mathrm{X}$ is usually $\mathrm{Sb}$, in some cases Ti, typically with an exotic chemical composition reflecting the chemical composition of the former jamesonite. Jamesonite is enriched in $\mathrm{Bi}$ and $\mathrm{Se}$ (Table 2), which could be explained by a close relationship with Bi and Se minerals; the jamesonite crystallized with these Se- and Bi phases as the one of the latest minerals in the assemblage. Anomalous $\mathrm{Cu}$ contents $(<0.78 \mathrm{wt} \%)$, could be explained by interference from adjacent tetrahedrite or occupation by $\mathrm{Cu}$ of the free tetrahedral places in the jamesonite structure. Contents of Se vary from $0.9-2.6 \mathrm{wt} \%$, and of Bi from 9.3-14.2 wt\%. $\mathrm{The} \mathrm{Sb} /(\mathrm{Sb}+\mathrm{Bi})$ ratio is ca 0.8 which is higher than that in the coexisting tintinaite $(0.6)$. 

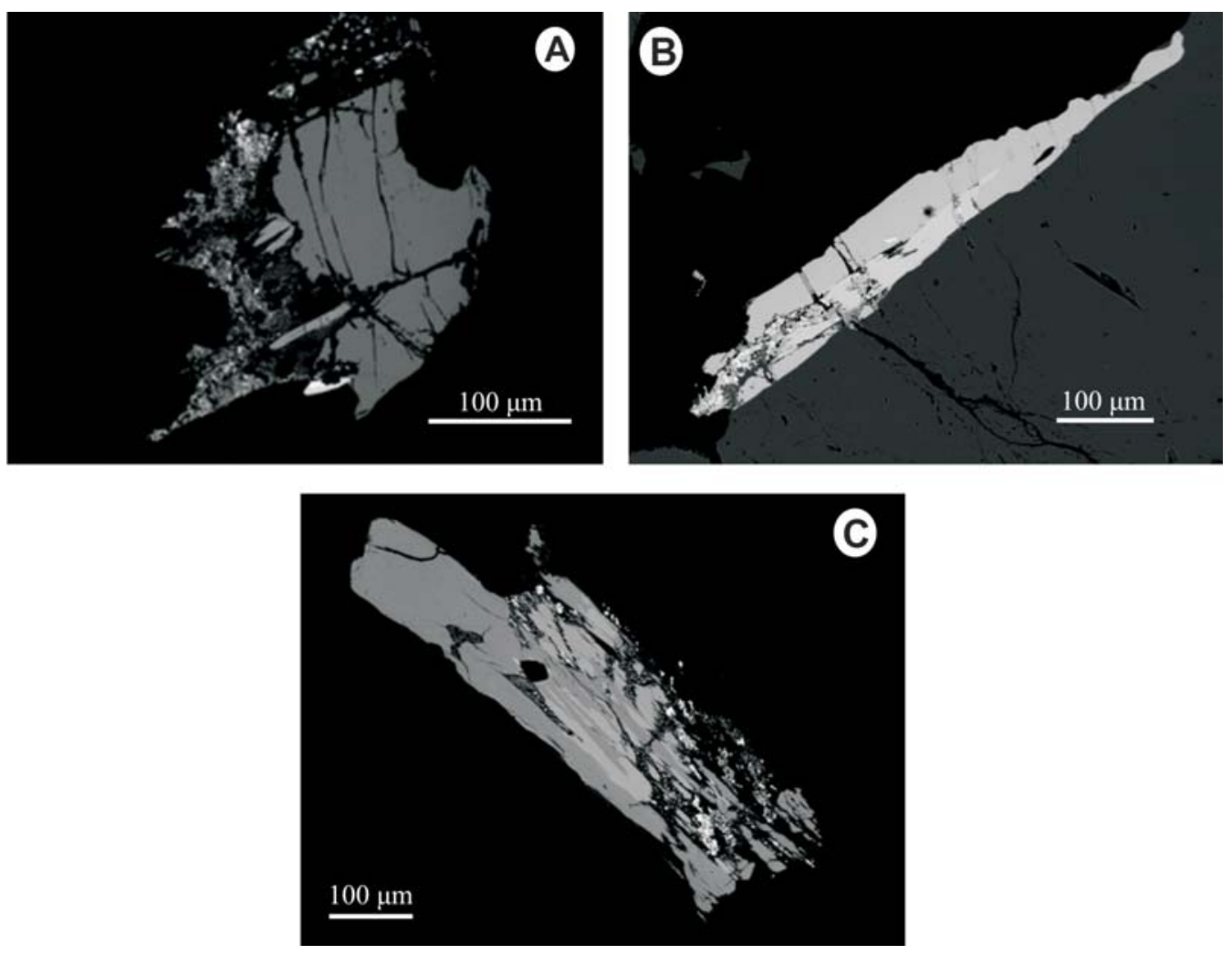

Fig. 2. A: Large irregular grain of Se-bearing jamesonite (dark grey) with small needles of tintinaite (light grey) and Bi-Se-Te phases (bright; upper part of the image) enclosed in tetrahedrite (black). B: Tetradymite (small bright inclusion in the centre of image) and members of the laitakarite-ikunolite solid solution (bright decomposition products) in tintinaite (light grey)-jamesonite (dark grey) intergrowths. C: Small inclusions of ikunolite (bright) in jamesonite (dark grey)-tintinaite intergrowths (light grey)

This could be due to the lesser tendency of $\mathrm{Bi}$ to enter the jamesonite structure compared to that of tintinaite. The identical $\mathrm{S} /(\mathrm{S}+\mathrm{Se})(0.97)$ in jamesonite and coexisting tintinaite indicates co-precipitation of the two minerals from solution. The general formula of jamesonite (calculation based on a total of $\mathrm{Sb}+\mathrm{Bi}+\mathrm{Pb}=10$ ) is $\mathrm{Fe}_{0.97} \mathrm{Cu}_{0.12} \mathrm{Sb}_{4.81} \mathrm{Bi}_{1.25} \mathrm{~Pb}_{3.94} \mathrm{~S}_{13.22} \mathrm{Se}_{0.38} \mathrm{Cl}_{0.01}$.

\subsection{Tintinaite}

Tintinaite is the second most abundant sulphosalt in the material studied. Like jamesonite, with which it is intergrown (Fig. 2A-C), it forms needle-like crystals to $1 \mathrm{~mm}$ long and contains minute grains and decomposition products of Bi-, Se and Te phases. The microprobe data show the chemical composition to extends along the kobellite-tintinaite solid solution series with a prevalence of $\mathrm{Sb}$ over $\mathrm{Bi}\left(\mathrm{M}^{3+}\right.$ elements) and a dominance of $\mathrm{Cu}$ (from 1.7-1.9 apfu) in the tetrahedral positions, which also containing Fe (from $0.25-0.47 \mathrm{apfu}$ ). The sum of the tetrahedrally coordinated cations $(\mathrm{T})$ is higher than 2 - the ideal value for phases in the 
Electron microprobe analyses of jamesonite with crystallochemical formulas calculated on the basis of $\mathrm{Sb}+\mathrm{Bi}+\mathrm{Pb}=10$

\begin{tabular}{|c|c|c|c|c|c|c|c|c|}
\hline Sample & $\mathrm{Sb}$ & $\mathrm{S}$ & $\mathrm{Cu}$ & $\mathrm{Bi}$ & $\mathrm{Fe}$ & $\mathrm{Pb}$ & $\mathrm{Se}$ & Total \\
\hline \multicolumn{9}{|c|}{ Weight \% } \\
\hline Р 33 & 28.17 & 20.01 & 0.78 & 9.29 & 2.54 & 38.15 & 1.23 & 100.18 \\
\hline P 34 & 26.29 & 19.66 & 0.25 & 12.37 & 2.43 & 38.22 & 1.13 & 100.36 \\
\hline Р 34 & 24.96 & 18.99 & 0.46 & 14.21 & 2.43 & 36.75 & 2.62 & 100.44 \\
\hline UH-03 & 28.69 & 19.05 & 0.76 & 9.89 & 2.51 & 36.67 & 1.63 & 99.18 \\
\hline UH-02 & 26.22 & 19.35 & 0.16 & 12.29 & 2.48 & 36.29 & 1.07 & 97.92 \\
\hline $\mathrm{n}=8$ & 26.65 & 19.44 & 0.36 & 11.92 & 2.46 & 37.12 & 1.36 & 99.33 \\
\hline \multicolumn{9}{|c|}{ Formula* } \\
\hline P 33 & 5.03 & 13.57 & 0.27 & 0.97 & 0.99 & 4.00 & 0.34 & \\
\hline Р 34 & 4.70 & 13.35 & 0.08 & 1.29 & 0.95 & 4.01 & 0.31 & \\
\hline Р 34 & 4.55 & 13.15 & 0.16 & 1.51 & 0.97 & 3.94 & 0.74 & \\
\hline UH-03 & 5.12 & 12.92 & 0.26 & 1.03 & 0.98 & 3.85 & 0.45 & \\
\hline UH-02 & 4.79 & 13.44 & 0.06 & 1.31 & 0.99 & 3.90 & 0.30 & \\
\hline $\mathrm{n}=8$ & 4.81 & 13.32 & 0.12 & 1.25 & 0.97 & 3.94 & 0.38 & \\
\hline
\end{tabular}

* Based on $\Sigma \mathrm{Pb}+\mathrm{Bi}+\mathrm{Sb}=11$ at.. As, $\mathrm{Cd}, \mathrm{Zn}, \mathrm{Ag}$ and Te are below detection limits, $\mathrm{n}=$ number of analyses used for mean composition calculation.

kobellite-tintinaite solid solution series (Zakrzewski, Makovicky 1986). Taking into account the type of substitutions and the methodology used in the calculations, $\mathrm{Cu}$ probably enters the structure via the aikinite-type substitution $(\mathrm{Cu}+\mathrm{Pb}=\mathrm{Bi}(\mathrm{Sb})+$ vac.). The $\mathrm{Cu}$ excess in the analyses has the same value as the deficiency of the $\mathrm{Bi}+\mathrm{Sb}$ contents from a total of 16 apfu. The latest classification of Moëlo et al. (2008) suggests $(\mathrm{Cu}, \mathrm{Fe})_{2} \mathrm{~Pb}_{11}(\mathrm{Bi}, \mathrm{Sb})_{15} \mathrm{~S}_{35}$ as the formula for kobellite and $\mathrm{Cu}_{2} \mathrm{~Pb}_{10} \mathrm{Sb}_{16} \mathrm{~S}_{35}$ for tintinaite. The low content of $\mathrm{Fe}$ and atomic ratios of $\mathrm{Pb}: \mathrm{Sb}+\mathrm{Bi}$ close to 10:16 suggests our phase to be tintinaite, not kobellite. Also, using the 50\% rule for solid solution series (Nickel 1992), we consider this phase as tintinaite, not kobellite.

The tintinaite is characterized (Table 3) by minor contents As $(<0.4 \mathrm{wt} \%), \mathrm{Cd}(<0.1 \mathrm{wt} \%)$, $\mathrm{Zn}(<0.04 \mathrm{wt} \%)$ and $\mathrm{Ag}(<0.3 \%)$. Arsenic is presumably accommodated via the simple $\mathrm{As} \leftrightarrow \mathrm{Bi}(\mathrm{Sb})$ substitution and $\mathrm{Cd}$ and $\mathrm{Zn}$ replace $\mathrm{Pb}$, i.e. $\mathrm{Cd}(\mathrm{Zn}) \leftrightarrow \mathrm{Pb}$. Silver probably enters the structure via lillianite-type of substitution i.e. $\mathrm{Ag}+\mathrm{Bi}(\mathrm{Sb})=2 \mathrm{~Pb}$. The degree to which $\mathrm{Pb}$ falls below an apfu value of 10 matches the content of $\mathrm{Ag}$ entering the structure by this type of substitution with adequate content of $\mathrm{Sb}$ or $\mathrm{Bi}$. The total content of $\mathrm{M}^{2+}$ elements is 9.9 and those of $\mathrm{Ag}, \mathrm{T}$ and $\mathrm{M}^{3+}$ are $0.1,2.13$ and 15.99 respectively (all values calculated from the mean empirical composition). Using the lillianite substitution $0.1 \mathrm{Ag}+0.1 \mathrm{Bi}(\mathrm{Sb})=0.2 \mathrm{~Pb}$, gives $\mathrm{M}^{2+}$ and $\mathrm{M}^{3+}$ values 10.1 and 15.89 respectively and the same $\mathrm{T}$ value. The aikinite substitution 
Electron microprobe analyses of tintinaite with calculation of $\mathrm{N}$ (homologne number) and crystallochemical formulas on the basis of $\mathrm{Sb}+\mathrm{Bi}+\mathrm{Pb}+\mathrm{Ag}=26$

\begin{tabular}{|c|c|c|c|c|c|c|c|c|c|c|c|c|c|}
\hline Sample & $\mathrm{Ag}$ & $\mathrm{Sb}$ & $\mathrm{S}$ & $\mathrm{Cu}$ & $\mathrm{Bi}$ & As & $\mathrm{Fe}$ & $\mathrm{Cl}$ & $\mathrm{Pb}$ & $\mathrm{Cd}$ & $\mathrm{Zn}$ & $\mathrm{Se}$ & Total \\
\hline \multicolumn{14}{|c|}{ Weight $\%$} \\
\hline P 34 & n.d. & 21.77 & 18.64 & 1.89 & 20.27 & n.d. & 0.45 & n.d. & 36.37 & n.d. & n.d. & 1.52 & 100.93 \\
\hline UH-02 & 0.19 & 19.24 & 17.98 & 1.94 & 22.76 & 0.39 & 0.33 & 0.07 & 34.05 & 0.02 & 0.03 & 1.66 & 98.66 \\
\hline UH-02 & 0.17 & 19.34 & 18.05 & 2.07 & 22.39 & 0.00 & 0.34 & 0.11 & 34.91 & 0.09 & 0.06 & 1.23 & 98.73 \\
\hline UH-02 & 0.26 & 19.52 & 18.39 & 1.91 & 22.89 & 0.19 & 0.27 & 0.05 & 34.11 & 0.00 & 0.04 & 1.28 & 98.90 \\
\hline UH-02 & 0.26 & 19.38 & 18.04 & 1.90 & 23.34 & 0.00 & 0.23 & 0.03 & 33.87 & 0.08 & 0.05 & 1.20 & 98.39 \\
\hline UH-01 & 0.16 & 20.07 & 17.96 & 1.94 & 21.76 & 0.00 & 0.24 & 0.03 & 34.06 & 0.11 & 0.00 & 2.06 & 98.39 \\
\hline $\mathrm{n}=8$ & 0.22 & 19.68 & 18.14 & 1.93 & 22.60 & 0.10 & 0.30 & 0.05 & 34.41 & 0.06 & 0.03 & 1.46 & 98.92 \\
\hline \multicolumn{13}{|c|}{ Formula* } & $\mathrm{N}$ \\
\hline P 34 & n.d. & 10.30 & 33.48 & 1.72 & 5.59 & n.d. & 0.47 & n.d. & 10.11 & n.d. & n.d. & 1.11 & 1.92 \\
\hline UH-02 & 0.10 & 9.36 & 33.22 & 1.81 & 6.45 & 0.31 & 0.35 & 0.11 & 9.73 & 0.01 & 0.03 & 1.25 & 1.92 \\
\hline UH-02 & 0.09 & 9.44 & 33.45 & 1.93 & 6.36 & 0.00 & 0.36 & 0.18 & 10.01 & 0.05 & 0.05 & 0.92 & 1.99 \\
\hline UH-02 & 0.14 & 9.47 & 33.91 & 1.78 & 6.47 & 0.15 & 0.28 & 0.08 & 9.73 & 0.00 & 0.03 & 0.96 & 1.94 \\
\hline UH-02 & 0.15 & 9.44 & 33.39 & 1.77 & 6.63 & 0.00 & 0.25 & 0.05 & 9.70 & 0.04 & 0.04 & 0.90 & 1.96 \\
\hline UH-01 & 0.09 & 9.83 & 33.42 & 1.82 & 6.21 & 0.00 & 0.25 & 0.05 & 9.81 & 0.06 & 0.00 & 1.56 & 1.95 \\
\hline $\mathrm{n}=8$ & 0.10 & 9.55 & 33.51 & 1.80 & 6.38 & 0.06 & 0.33 & 0.09 & 9.86 & 0.02 & 0.02 & 1.11 & 1.96 \\
\hline
\end{tabular}

* Based on $\Sigma \mathrm{Ag}+\mathrm{Pb}+\mathrm{Bi}+\mathrm{Sb}+\mathrm{Zn}+\mathrm{Cd}+\mathrm{As}=26$ at., n.d. - not determined, Te is below detection limit, $\mathrm{n}=$ number of analyses used for mean composition calculation.

$0.13 \mathrm{Cu}+0.13 \mathrm{~Pb}=0.13 \mathrm{Bi}(\mathrm{Sb})+$ vac. gives $\mathrm{M}^{2+}$ and $\mathrm{M}^{3+}$ values of 9.97 and 16.02 , respectively that are very close to the ideal tintinaite composition $\mathrm{T}_{2} \mathrm{M}^{2+}{ }_{10} \mathrm{M}^{3+}{ }_{16} \mathrm{~S}_{35}$. The Se content is variable and ranges from 1.2-2.06 wt $\%$, corresponding to $0.9-1.56 \mathrm{apfu}$. The $\mathrm{Cl}$ content is $<0.1 \mathrm{wt} \%$. The content of sulphur anions deviates from the ideal composition. The calculated $\mathrm{N}$ varies from the 1.92-1.99 - in good agreement with that calculated for the members of the kobellite-tintinaite series $(\mathrm{N}=2)$. A general formula of the tintinaite, calculated on the basis of the total of all cations (excepting the tetrahedral coordinated $=26$ ) is:

$\left(\mathrm{Cu}_{1.8} \mathrm{Fe}_{0.33}\right)_{2.13}\left(\mathrm{~Pb}_{9.86} \mathrm{Cd}_{0.02} \mathrm{Zn}_{0.02}\right)_{9.90}\left(\mathrm{Sb}_{9.55} \mathrm{Bi}_{6.38} \mathrm{Ag}_{0.1} \mathrm{As}_{0.06}\right)_{16.09}\left(\mathrm{~S}_{33.51} \mathrm{Se}_{1.11} \mathrm{Cl}_{0.09}\right)_{34.71 \text {. }}$

\subsection{Bournonite}

Rare bournonite occurs as small $(<10 \mu \mathrm{m})$ inclusions in tetrahedrite. As with all sulphosalts, the bournonite contains small amounts of Se and $\mathrm{Bi}$. The contents of Se vary from 1.6-1.66 wt\% and those of Bi from 1.16-1.34 wt\% (Table 4). Small amounts of $\mathrm{Zn}$ and $\mathrm{Fe}(<0.1 \mathrm{wt} \%)$, could be explained by the small size of the bournonite grains and its position within tetra- 
Electron microprobe analyses of bournonite with crystallochemical formulas calculated on the basis of total cations $=3$

\begin{tabular}{ccccccccc}
\hline Sample & $\mathrm{Cu}$ & $\mathrm{Sb}$ & $\mathrm{Bi}$ & $\mathrm{Pb}$ & $\mathrm{Fe}$ & $\mathrm{S}$ & $\mathrm{Se}$ & Total \\
\hline UH-01 & 13.00 & 23.73 & 1.16 & 41.89 & 0.10 & 18.73 & 1.60 & 100.36 \\
$\mathrm{UH}-01$ & 12.98 & 23.54 & 1.34 & 41.85 & 0.09 & 18.74 & 1.66 & 100.32 \\
\hline & & & Formula* & & & \\
\hline UH-01 & 1.00 & 0.96 & 0.03 & 0.99 & 0.01 & 2.87 & 0.10 \\
UH-01 & 1.01 & 0.95 & 0.03 & 1.00 & 0.01 & 2.88 & 0.10 \\
\hline
\end{tabular}

* Based on $\Sigma$ cations $=3, \mathrm{Te}, \mathrm{Cl}, \mathrm{Zn}, \mathrm{Cd}, \mathrm{Ag}$ are below detection limits.

hedrite. A general formula for the bournonite may be calculated (on the basis of 3 cations) as: $\mathrm{Cu}_{1,01}\left(\mathrm{~Pb}_{0.99} \mathrm{Fe}_{0.01} \mathrm{Zn}_{0.01}\right)_{1.01}\left(\mathrm{Sb}_{0.95} \mathrm{Bi}_{0.03}\right)_{0.98}\left(\mathrm{~S}_{2.87} \mathrm{Se}_{0.10}\right)_{2.97}$.

\subsection{Bi-Se-Te-S phases (tetradymite group)}

Bi-Se-Te minerals are common. They form, together with native bismuth, complex decomposition products of pre-existing unknown minerals (Fig. $2 \mathrm{C})$ or small $(<50 \mu \mathrm{m})$ needles or laths enclosed in tetrahedrite, jamesonite and tintinaite. Several phases have been identified using the electron probe microanalyses (Fig. 3). Minerals of the laitakarite-ikunolite solid solution series are the most common; tetradymite less so. Of other unnamed phases found, one has a composition close to $\mathrm{X}_{3} \mathrm{~S}_{4}$ and another, with a composition close to $\mathrm{Bi}_{7} \mathrm{Te}_{2} \mathrm{Se}$, is probably a Se-rich analogue of hedleyite $\left(\mathrm{Bi}_{7} \mathrm{Te}_{3}\right)$.

Tetradymite forms small $(<50 \mu \mathrm{m})$ acicular crystals enclosed in tintinaite (Fig. 2B), tetrahedrite or jamesonite. Unlike the other minerals of the group, it does not occur as a product of decomposition. It has a homogenous chemical composition with minor amounts of $\mathrm{Sb}(0.02-0.1 \mathrm{apfu}), \mathrm{Cu}(<0.2), \mathrm{Pb}(<0.07)$ and $\mathrm{Se}(0.17-0.31)$. The Se contents move the analyses towards the field of kawazulite (Se-rich end-member of the tetradymite-kawazulite solid solution series). That $\mathrm{Cu}$ was not identified in all analyses suggests that any measured derived from hosting tintinaite or tetrahedrite. The general formula for tetradymite is $\left(\mathrm{Bi}_{1.84} \mathrm{Sb}_{0.05} \mathrm{Cu}_{0.05} \mathrm{~Pb}_{0.04} \mathrm{Fe}_{0.02}\right)_{2.00} \mathrm{Te}_{1.78}\left(\mathrm{~S}_{0.84} \mathrm{Se}_{0.26}\right)_{1.10}$.

Hedleyite, very rare; was identified as small $(5 \mu \mathrm{m})$ acicular crystals together with tetradymite as inclusions in tetrahedrite. In comparison with theoretical hedleyite $\mathrm{Bi}_{7} \mathrm{Te}_{3}, \mathrm{Sb}$ $(0.69 \mathrm{apfu})$ and $\mathrm{Pb}(0.16)$ contents tend to be higher. Te position is strongly substituted. Its content of selenium is 0.88 apfu and of sulphur 0.25 apfu. Based on a total of 7 cations (excluding $\mathrm{Fe}$ and $\mathrm{Cu}$ ), the anion content of 3.62 exceeds that in theoretical hedleyite. When calculated with $\mathrm{Cu}$ and $\mathrm{Fe}$, the anion content, at 3.35 , is closer to the theoretical value. The high content of $\mathrm{Sb}$ and $\mathrm{Se}+\mathrm{S}$ contents could indicate possibly either another phase than hedleyite or the mixture of hedleyite with tetrahedrite or another phase. The contents of Fe and 


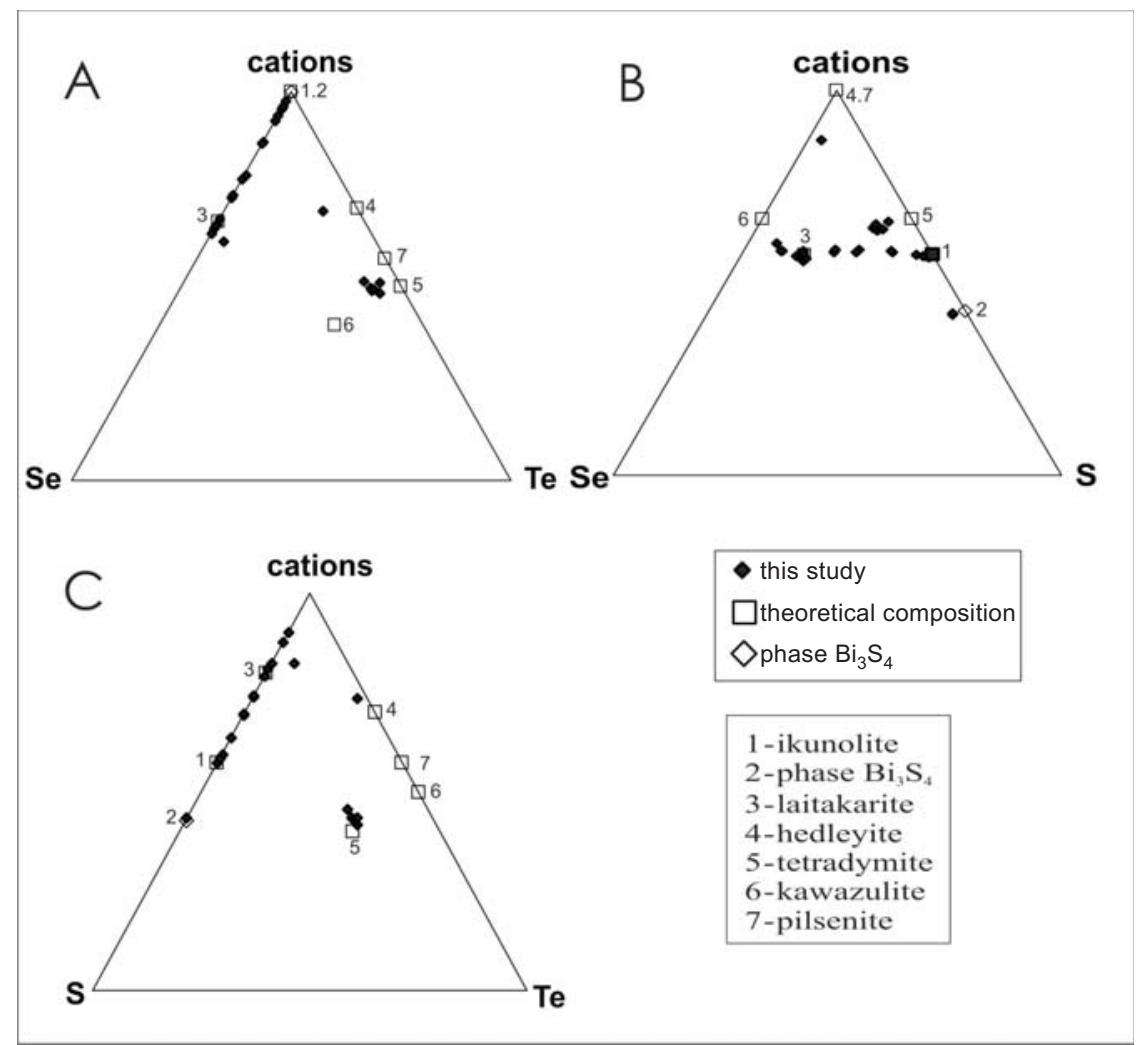

Fig. 3. Triangular compositional plots in the systems (a) Bi-Se-Te, (b) Bi-Se-S and (c) Bi-S-Te for the tetradymite group phases identified at Úhorná

$\mathrm{Cu}$ and the proportion of cations to anions without $\mathrm{Cu}$ and $\mathrm{Fe}(7: 3.62)$ and with $\mathrm{Fe}$ and $\mathrm{Cu}$ (7:3.35) indicate the influence of tetrahedrite in the analyses. The formula of hedleyite is $\left(\mathrm{Bi}_{6.15} \mathrm{Sb}_{0.69} \mathrm{~Pb}_{0.16}\right)_{7.00}\left(\mathrm{Te}_{2.49} \mathrm{Se}_{0.88} \mathrm{~S}_{0.25}\right)_{3.62}$.

An unnamed phase, with a composition close to $\mathrm{Bi}_{3} \mathrm{~S}_{4}$, occurs with laitakarite as small $(<5 \mu \mathrm{m})$ inclusions in tetrahedrite. Based on 3 cations, it contains greater amounts of $\mathrm{Sb}(<1$ apfu) and lesser $\mathrm{Cu}(0.25)$ and $\mathrm{Se}(0.24)$. It could be a Sb-Se-rich analogue of $\mathrm{Bi}_{3} \mathrm{~S}_{4}$, or possibly a phase close to $\mathrm{Bi}_{2} \mathrm{SbS}_{4}$. The general formula might be written as $\mathrm{Bi}_{1.7} \mathrm{Sb}_{0.93} \mathrm{As}_{0.07} \mathrm{Cu}_{0.25} \mathrm{Fe}_{0.03} \mathrm{~S}_{3.84} \mathrm{Se}_{0.24}$.

The minerals of the laitakarite (ideally $\mathrm{Bi}_{4} \mathrm{Se}_{3}$, but more commonly $\sim \mathrm{Bi}_{4}(\mathrm{Se}, \mathrm{S})_{3}$ )-ikunolite (generally $\mathrm{Bi}_{4} \mathrm{~S}_{3}$ ) solid solutions series display strong variation in their Se:S ratio (Fig. 4). Te contents are very low $(<0.26 \mathrm{apfu})$. Sulphur contents in the laitakarite itself vary from 0.42-1.4 apfu, and selenium from 2.29-1.49. In contrast, sulphur contents in ikunolite vary from 2.98-1.75 and selenium from 0.1-1.16. Moreover, as with the other minerals, the laitakarite-ikunolite phases also contain small amounts of other elements (Table 5) mainly Sb (0.02-0.26 apfu), $\mathrm{Pb}(<0.28), \mathrm{Cu}(<0.23)$ and $\mathrm{Fe}(<0.05)$. Some of these contents could be spurious matrix contaminations due to the very small grain size of the Bi-Se-Te phases and their occurring within tetrahedrite or other sulphosalts. As minerals of the laitakarite-ikunolite series 


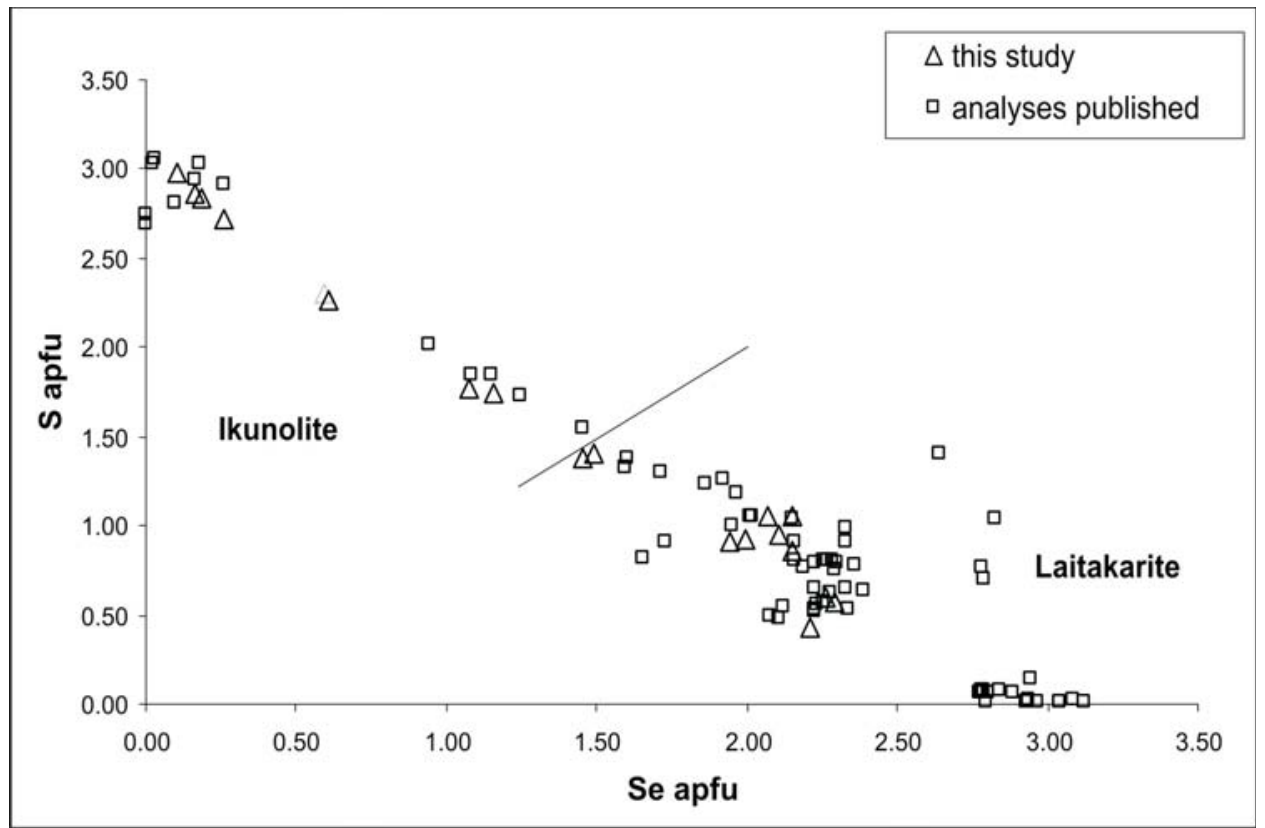

Fig. 4. Diagram showing compositions, in terms of S vs. Se, for phases of the laitakarite-ikunolite solid solution series from Úhorná compared with literature data

Localities: Highis (RO) - Ciobanu et al. (2006), Orthosa (ESP) - Cepedal et al. (2006), Kairagach (UZB) -

Plotinskaya et al. (2006), Zálesí (CZ) - Fojt \& Škoda (2005), Boliden (SWE) - Wagner \& Jonsson (2001),

Neves Corvo, San Miguel (POR) - Marcoux et al. (1996), Radlin (PL) - Piestrzynski (1992), Verchne Semjanskoe, Nevskoe (RUS) - Zavyalov et al. (1983), Kidd Creek (CAN) - Pringle \& Thorpe (1980), Vysokogorskoe (RUS) Finashin et al. (1979), Falun (SWE) - Strunz (1963), Zavyalov et al. (1983), Kingsgate (GB) - Markham (1962), Orvijarvi (FIN) - Vorma (1959), Zavyalov et al. (1983), Orlovskoe (RUS) - Aksenov et al. (1968), Russia - Godovikov \& Feryanchich (1960), Ikuno (JAP) - Kato (1959)

display pronounced degrees of substitution, no general formula could be written. However, the range of substitution varies from $\left(\mathrm{Bi}_{3.82} \mathrm{Cu}_{0.14} \mathrm{Sb}_{0.02} \mathrm{Fe}_{0.02}\right)_{4.00}\left(\mathrm{~S}_{2.98} \mathrm{Se}_{0.10}\right)_{3.08}$ to $\left(\mathrm{Bi}_{3.81} \mathrm{Sb}_{0.13}\right.$ $\left.\mathrm{Pb}_{0.04} \mathrm{Cu}_{0.02}\right)_{4.00}\left(\mathrm{Se}_{2.29} \mathrm{~S}_{0.57}\right)_{2.86}$. The formulae for individual members of the series and for the other members of the tetradymite group are given in Tables 5 and 6 .

\section{Discussion}

Selenium and tellurium minerals are relatively rare in hydrothermal mineralizations in the Western Carpathians. Chemically homogenous tetradymite without any Se substitution occurs in association with scheelite and bismuth minerals at Dúbrava (Chovan, Michálek 1988), in Au mineralization at Katarínska Huta (Ferenc 2004) and Kokava nad Rimavicou (Ferenc, Bakos $2006)$ and, with a very small amount of $\mathrm{Se}(<0.68 \mathrm{wt} \%)$ in the volcanic Bi-Te mineralization in Župkov (Sejkora et al. 2004). In comparison, tetradymite from Uhorná contains a small amount of Se (or the kawazulite molecule) up to $0.31 \mathrm{apfu}$ (3.64 wt\%). Various contents of Se $(0.5-4.1 \mathrm{wt} \%)$ characterize tetradymite associated with other Bi sulphotellurides in the Larga 
TABLE 5

Electron microprobe analyses of selenides, tellurides and their crystallochemical formulas

\begin{tabular}{|c|c|c|c|c|c|c|c|c|c|}
\hline Sample & $S b$ & $\mathrm{~S}$ & $\mathrm{Cu}$ & $\mathrm{Bi}$ & $\mathrm{Fe}$ & $\mathrm{Pb}$ & $\mathrm{Se}$ & $\mathrm{Te}$ & Total \\
\hline \multicolumn{10}{|c|}{ Weight \% } \\
\hline UH-03 & 0.24 & 10.38 & 0.98 & 86.81 & 0.12 & 0.00 & 0.87 & 0.03 & 99.44 \\
\hline UH-03 & 0.69 & 9.47 & 0.85 & 86.03 & 0.03 & 0.74 & 2.21 & 0.05 & 100.08 \\
\hline UH-03 & 0.62 & 7.81 & 1.05 & 84.20 & 0.18 & 0.33 & 5.14 & 0.06 & 99.39 \\
\hline UH-03 & 0.52 & 5.90 & 1.06 & 81.59 & 0.12 & 0.77 & 8.85 & 0.26 & 99.07 \\
\hline UH-03 & 0.43 & 4.56 & 1.49 & 73.70 & 0.16 & 5.89 & 11.82 & 0.04 & 98.09 \\
\hline Р 34 & 2.05 & 2.92 & 0.27 & 77.84 & n.d. & 0.83 & 15.26 & 0.06 & 99.24 \\
\hline P 34 & 0.80 & 2.92 & 0.04 & 80.02 & n.d. & 0.29 & 15.43 & 0.04 & 99.54 \\
\hline P 34 & 1.58 & 1.80 & 0.12 & 78.28 & n.d. & 0.75 & 17.80 & 0.00 & 100.32 \\
\hline P 34 & 2.00 & 1.33 & 0.13 & 76.36 & n.d. & 1.32 & 17.01 & 0.08 & 98.22 \\
\hline UH-02 & 0.33 & 3.97 & 0.09 & 57.97 & 0.03 & 1.53 & 3.32 & 32.21 & 99.45 \\
\hline UH-02 & 0.43 & 3.90 & 0.06 & 59.63 & 0.05 & 1.96 & 3.64 & 30.41 & 100.08 \\
\hline UH-01 & 0.83 & 3.77 & 0.02 & 57.53 & 0.07 & 1.37 & 3.30 & 33.40 & 100.28 \\
\hline $\mathrm{n}=7$ & 0.90 & 3.90 & 0.43 & 56.03 & 0.21 & 1.20 & 3.01 & 33.01 & 98.69 \\
\hline UH-02 & 4.63 & 0.45 & 1.42 & 70.71 & 0.64 & 1.82 & 3.84 & 17.50 & 101.00 \\
\hline \multicolumn{10}{|c|}{ Formula* } \\
\hline & $\mathrm{Sb}$ & $\mathrm{S}$ & $\mathrm{Cu}$ & $\mathrm{Bi}$ & $\mathrm{Fe}$ & $\mathrm{Pb}$ & $\mathrm{Se}$ & $\mathrm{Te}$ & mineral \\
\hline UH-03 & 0.02 & 2.98 & 0.14 & 3.82 & 0.02 & 0.00 & 0.10 & 0.00 & ikunolite \\
\hline UH-03 & 0.05 & 2.72 & 0.12 & 3.79 & 0.00 & 0.03 & 0.26 & 0.00 & ikunolite \\
\hline UH-03 & 0.05 & 2.27 & 0.15 & 3.75 & 0.03 & 0.02 & 0.61 & 0.00 & ikunolite \\
\hline UH-03 & 0.04 & 1.76 & 0.16 & 3.74 & 0.02 & 0.04 & 1.07 & 0.02 & ikunolite \\
\hline UH-03 & 0.03 & 1.38 & 0.23 & 3.43 & 0.03 & 0.28 & 1.46 & 0.00 & laitakarite \\
\hline Р 34 & 0.17 & 0.92 & 0.04 & 3.75 & n.d. & 0.04 & 1.94 & 0.00 & laitakarite \\
\hline Р 34 & 0.07 & 0.93 & 0.01 & 3.91 & n.d. & 0.01 & 2.00 & 0.00 & laitakarite \\
\hline P 34 & 0.13 & 0.57 & 0.02 & 3.81 & n.d. & 0.04 & 2.29 & 0.00 & laitakarite \\
\hline P 34 & 0.17 & 0.42 & 0.02 & 3.75 & n.d. & 0.07 & 2.21 & 0.01 & laitakarite \\
\hline UH-02 & 0.02 & 0.86 & 0.01 & 1.92 & 0.00 & 0.05 & 0.29 & 1.74 & tetradymite \\
\hline UH-02 & 0.02 & 0.81 & 0.01 & 1.90 & 0.01 & 0.06 & 0.31 & 1.59 & tetradymite \\
\hline UH-01 & 0.05 & 0.81 & 0.00 & 1.90 & 0.01 & 0.05 & 0.29 & 1.80 & tetradymite \\
\hline $\mathrm{n}=7$ & 0.05 & 0.83 & 0.05 & 1.84 & 0.03 & 0.04 & 0.26 & 1.77 & tetradymite \\
\hline UH-02 & 0.69 & 0.25 & 0.41 & 6.15 & 0.21 & 0.16 & 0.88 & 2.49 & hedleyite \\
\hline
\end{tabular}

* Formula of the laitakarite-ikunolite phases based on $\Sigma$ cations $=4$, for tetradymite based on $\Sigma$ cations $=2$, for hedleyite based on $\Sigma$ cations (excluding $\mathrm{Fe}$ and $\mathrm{Cu}$ ) $=7$, n.d. - not determined, $\mathrm{n}=$ number of analyses used for mean composition calculation.

98 
TABLE 6

Electron microprobe analyses of the phase $\mathrm{X}_{3} \mathrm{~S}_{4}$ and its crystallochemical formula based on total cations $=3$

\begin{tabular}{cccccccccccc}
\hline Sample & $\mathrm{Bi}$ & $\mathrm{Sb}$ & $\mathrm{As}$ & $\mathrm{Cu}$ & $\mathrm{Fe}$ & $\mathrm{Pb}$ & $\mathrm{Cd}$ & $\mathrm{Zn}$ & $\mathrm{S}$ & $\mathrm{Se}$ & $\mathrm{Total}$ \\
\hline \multicolumn{7}{c}{ Weight $\%$} \\
\hline UH-03 & 56.59 & 18.52 & 1.43 & 2.41 & 0.21 & 0.25 & 0.11 & 0.09 & 19.69 & 2.88 & 102.19 \\
$\mathrm{UH}-03$ & 57.20 & 18.18 & 0.90 & 2.55 & 0.24 & 0.22 & 0.03 & 0.14 & 19.60 & 2.99 & 102.07 \\
\hline & & & & Formula* & & & & \\
\hline UH-03 & 1.67 & 0.94 & 0.12 & 0.23 & 0.02 & 0.01 & 0.01 & 0.01 & 3.78 & 0.22 & $\mathrm{X}_{3} \mathrm{~S}_{4}$ \\
UH-03 & 1.70 & 0.93 & 0.07 & 0.25 & 0.03 & 0.01 & 0.00 & 0.01 & 3.80 & 0.24 & $\mathrm{X}_{3} \mathrm{~S}_{4}$ \\
\hline
\end{tabular}

$*$ Based on $\Sigma$ cations $=3$, Te and Ag are below detection limits.

hydrothermal system, Romania (Cook, Ciobanu 2004). Similar Se contents (0.95-4 wt\%) have been reported from tetradymite occurring with rucklidgeite, kawazulite, Sb kawazulite and tellurobismuthite from the Kairagach and Kochbulak hydrothermal deposits, Uzbekistan (Plotinskaya et al. 2006).

Based on published data, a complete solid-solution series between kawazulite and tetradymite was proposed by Cook et al. (2007). All of them show minor deviations from $\mathrm{Bi}_{2} \mathrm{Te}_{2} \mathrm{~S}-\mathrm{Bi}_{2} \mathrm{Te}_{2} \mathrm{Se}$. The authors suggest that this may be due to analytical error, or to limited Se-for-Te substitution as previously proposed by Bayliss (1991).

The phase compositionally close to hedleyite is characterized by high contents of $\mathrm{Sb}$ (0.69 apfu) and $\mathrm{Pb}(0.16 \mathrm{apfu})$. The contents of $\mathrm{Fe}(0.21 \mathrm{apfu})$ and $\mathrm{Cu}(0.4)$ could relate to the surrounding tetrahedrite rather than to any substitution and, likewise, the similar Fe content reported by Haruna et al. (2002). Cook et al. (2007) proposed that only S, Se, Sb and Pb could enter to the structure of hedleyite and not $\mathrm{Cu}$ or Fe. In hedleyite from other places, the contents of the permitted elements are quite low. A maximum content of $\mathrm{Sb}(0.15 \mathrm{apfu})$ is reported by Cepedal et al. (2006) from Orthosa (Spain). Practically no contents of Pb have been published. Haruna et al. (2002) and Cepedal et al. (2006) reported < 0.05 apfu of Se in hedleyite; neither noted any S. The hedleyite from Uhorná is characterized, in contrast, by high Se contents $(<0.88 \mathrm{apfu})$ and $\mathrm{S}(<0.25 \mathrm{apfu})$. The anion total is also higher $(<0.62 \mathrm{apfu})$ than the theoretical value ( $3 \mathrm{apfu})$. A similar anion excess $(<0.44 \mathrm{apfu})$ in hedleyite was reported by Cepedal et al. (2006) but Haruna et al. (2002) have reported an anion deficit (0.51 apfu).

The isostructural relation between laitakarite and ikunolite, both with R3m symmetry, should infer extensive solid-solution along the $\mathrm{Bi}_{4} \mathrm{~S}_{3}$ and $\mathrm{Bi}_{4} \mathrm{Se}_{3}$ join. Based on literature data, Wagner and Jonsson (2001) proposed limited solid solution between laitakarite and ikunolite; they found that analyses of ikunolite approximate the ideal composition whereas analyses of laitakarite display broad substitution of Se and $\mathrm{S}$ with $\mathrm{Se}: \mathrm{S}$ of most reported analyses concentrated close to 2:1. Fojt and Škoda (2005) described $\mathrm{a} \mathrm{Bi}_{4} \mathrm{Se}_{3}$ free end-member and Piestrzyński (1992) a similar phase with a higher $\mathrm{Cu}$ content. Cook et al. (2007) published laitakarite analyses close to $\mathrm{Bi}_{4} \mathrm{Se}_{2} \mathrm{~S}$ and $\mathrm{Bi}_{4} \mathrm{Se}_{3}$ compositions from the type locality. In contrast, analyses of laitakarite-ikunolite solid-solution minerals from Úhorná show a very broad range of Se versus $\mathrm{S}$ 
substitution with individual phases characterized by $\mathrm{S}:$ Se proportions of $3: 0,2.5: 0.5,1.5: 1.5$ and 1:2 (Fig. 4). Comparing the literature data with our results, a complete solid solution between $\mathrm{Bi}_{4} \mathrm{Se}_{3}$ and $\mathrm{Bi}_{4} \mathrm{~S}_{3}$ would appear to exist in natural samples (Fig. 6) with, possibly, a small gap between $\mathrm{Bi}_{4} \mathrm{Se}_{3}$ and $\mathrm{Bi}_{4} \mathrm{Se}_{2} \mathrm{~S}$. The boundary between laitakarite and ikunolite should thus be positioned at the $50 \%$ point as proposed by Nickel (1992) for similar solid-solutions.

Te contents in the minerals of the laitakarite-ikunolite solid solution are usually very low. Wagner and Jonsson (2001) reported $<9 \mathrm{wt} \% \mathrm{Te}$ in laitakarite from Boliden, Sweden. They also reported analyses of the ikunolite, pilsenite, joséite-A and joséite-B showing substitution along the $\mathrm{Bi}_{4} \mathrm{~S}_{3}-\mathrm{Bi}_{4} \mathrm{Te}_{3}$ join. They found that analyses of the individual phases show close to ideal stoichiometry and, thus, considered that the degree of Te versus $\mathrm{S}$ substitution between ikunolite and pilsenite was limited. On the other hand, Cook et al. (2007) reported 7.4-14.5 wt\% Te in laitakarite from Lega Dembi, Ethiopia and, on the basis of their own and others data, proposed solid-solution between $\mathrm{Bi}_{4} \mathrm{Se}_{2} \mathrm{~S}$ and $\mathrm{Bi}_{4} \mathrm{TeSe}_{2}$.

The concentration of selenium in the $\mathrm{Pb}-\mathrm{Sb}$ (Bi) sulphosalts is not common in the Western Carpathians samples. Peterec (1996), who studied material from the same locality as reported on here using EDX, described Se in sulphosalts such as pekoite, bismuthinite and others. Ragan and Caňo (1991) reported $<0.11 \mathrm{wt} \% \mathrm{Se}$ in meneghinite and $<4.49 \mathrm{wt} \%$ Se in members of the lillianite-gustavite solid solution associated with laitakarite.

Globally, selenium is a common element in the structure of sulphosalts (Mumme 1975; Marcoux et al. 1996; Cook 1998; Borodayev et al. 1998; Vurro et al. 1999; Wagner and Jonsson 2001, and many others). However, nearly all these minerals are Bi sulphosalts in which Se may actually be dominant, e.g., junoite, wittite, weibullite or could be a typical minor, substituting element, e.g., as in pekoite, lillianite homologous and others. Wagner, Jonsson (2001) described Se-bearing kobellite and bournonite associated with Te-bearing laitakarite in vein mineralization in the Boliden massive sulphide deposit. The $\mathrm{Sb} /(\mathrm{Sb} \mathrm{Bi})$ of the kobellite from Boliden (0.61) is very similar to that in the Úhorná tintinaite (0.60). Wagner and Jonsson (2001) identified the Boliden phase as kobellite using the calculation for the kobellite homologous series proposed by Zakrzewski and Makovicky (1986) and Moëlo et al. (1995), but without diffraction data. Recalculating the Boliden analysis using the formulas of tintinaite and kobellite proposed by Moëlo et al. (2008), confirms the Boliden phase to be kobellite; the $\mathrm{Pb}:(\mathrm{Sb}+\mathrm{Bi})$ of this phase is 11.2:14.78 (after $\mathrm{Ag}$ subtraction via $\mathrm{Ag}+\mathrm{Bi}=2 \mathrm{~Pb}$ substitution).

In contrast, the phase from Úhorna with a similar $\mathrm{Sb} /(\mathrm{Sb}+\mathrm{Bi})$ is tintinaite in which the $\mathrm{Pb}:(\mathrm{Sb}+\mathrm{Bi})$ is 10.1:15.89 (after $\mathrm{Ag}$ subtraction via $\mathrm{Ag}+\mathrm{Bi}=2 \mathrm{~Pb}$ substitution). The Se content of the Boliden samples $(<3.5 \mathrm{apfu})$ is higher than in the Úhorná material $(<1.25 \mathrm{apfu})$. $\mathrm{Se} /(\mathrm{Se}+\mathrm{S})$ in the tintinaite and bournonite from Úhorná $(0.03)$ is lower than that of the Boliden specimens (0.09); the activity of selenium was presumably lower in the former. The associated tetrahedrite from both localities is Se- and Te free. The laitakarite and bournonite at Boliden originated as a result of kobellite decomposition whereas the Úhorná laitakarite and tintinaite are primary minerals. Some amounts of laitakarite-ikunolite at Úhorná could also have originated through decomposition of an unknown mineral together with native bismuth.

Acknowledgments. Research was supported by research and equipment grants from the Slovak agency VEGA, grant number 1/1048/07. The authors wish to thank D. Ozdín for the EMPA analyses. Constructive reviews of Nigel J. Cook and Stanislav Jelen̆ as well as language correction by P. Kennan and A. Skowroński helped significantly improve the manuscript. 


\section{References}

AKSENOV V.S., ININ V.D., LITVINOVIC A.N., SLJUSAREVA A.P., KOSYAK E.A., 1968: Selenium-bearing minerals in ores of the Orlov pyrite polymetallic deposit in the Altai. Izvestija Akademie Nauk Kazakhskoj SSR. Serie Geologie 5, 42-52 (in Russian).

BÁlinTOVÁ, T., OZDÍN, D., 2006: Sulphosalts from Chyžné-Herichová in the Western Carpathians (Slovakia). Acta Mineralogica-Petrographica, Abstract Series 5, 8 .

BAYLISS P., 1991: Crystal chemistry and crystallography of some minerals in the tetradymite group. American Mineralogist 76, 257-265.

BEŇKA J., SUCHÝ Š., 1983: Mineralogical characterization of the tungsten ore deposit Jasenie-Kyslá. In: Scheelite-gold ore deposits in the Nízke Tatry Mts., Bratislava, GÚDŠ, 71-84 (in Slovak).

BLÁHA M., VITÁSEK A., 1991: Jasenie - North, VP. Unpublished manuscript. Geofond, Bratislava, 145 p. (in Slovak).

BORODAYEV Y.,S., GARAVELli A., KUZMINA O.V., MOZGOVA N.N., ORGANOVA N.I., TRUBKIN N.V., VURRO F., 1998: Rare sulphosalts from Vulcano, Aeolian Islands, Italy. I. Se-bearing kirkiite, $\mathrm{Pb}_{10}(\mathrm{Bi}, \mathrm{As})_{6}(\mathrm{~S}, \mathrm{Se})_{19}$. Canadian Mineralogist 36, 1105-1114.

CEPEDAL A., FUERTES-FUENTE M., MARTÍN-IZARD A., GONZÁLES-NISTAL S., RODRÍGUEZ-PEVIDA L., 2006: Tellurides, selenides and Bi-mineral assemblages from the Río Narcea Gold Belt, Asturias, Spain: genetic implications in $\mathrm{Cu}-\mathrm{Au}$ and $\mathrm{Cu}$ skarns. Mineralogy and Petrology 87, 277-304.

CHOVAN M., MICHÁLEK M., 1988: Bismuthinite and tetradymite from the Dúbrava Sb deposit. Mineralia Slovaca 20, 161-168 (in Slovak).

CIOBANU C.L., COOK N.J., DAMIAN F., DAMIAN G., 2006: Gold scavenged by bismuth melts: An example from Alpine shear-remobilizates in the Highiş Massif, Romania. Mineralogy and Petrology 87, 351-384.

COOK N.J., 1998: Bismuth sulphosalts from hydrothermal vein deposits of Neogene age, N.W. Romania. Mitteilungen der Österreichischen Mineralogischen Gesellschaft 143, 19-39.

COOK N.J., CIOBANU C.L., 2004: Bismuth tellurides and sulphosalts from the Larga hydrothermal system, Metaliferi Mts., Romania: Paragenesis and genetic significance. Mineralogical Magazine 68, 2, 301-321.

COOK N.J., CIOBANU C.L., WAGNERT., STANLEY C.J., 2007: Minerals of the system Bi-Te-Se-S related to the tetradymite archetype: Review of classification and compositional variation. Canadian Mineralogist 45, $665-708$.

ĎUĎA R., ČERNÝ P., KALIČIAK M., KALIČIAKOVÁ E., TŐZSÉR J., ULRICH J., VESELOVSKÝ F., 1981: Mineralogy of the north part of the Slanské vrchy Mts. Mineralia Slovaca - Monograph, Bratislava, 98 pp. (in Slovak).

ĎUĎA R., 1986: Altaite - a new telluride from the Zlatá Baňa deposit. Mineralia Slovaca 18, 1, 89-92 (in Slovak).

FERENC Š., 2004: New occurrences of the tellurium minerals in the west part of the Slovenské Rudohorie Mts. Mineralia Slovaca 36, 317-322 (in Slovak).

FERENC, Š., BAKOS, F., 2006: Au-Bi-Te mineralization in the Sinec shear zone (Kokava nad Rimavicou) - a new type of mineralization in the Western Carpathians. Mineralia Slovaca 38, 223-240. (in Slovak).

FINASHIN V.K., LITAVRINA R.F., ROMANENKO I.M., CHUBAROV V.M., 1979: Ikunolite from the Vysokogora deposit, Primorye. Zapisky Vsesojuznego Mineralogicheskego Obshchestva 108, 337-339 (in Russian).

FOJT B., ŠKODA R., 2005: $\mathrm{Bi}_{4} \mathrm{Se}_{3}$ and ikunolite-laitakarite from the uranium deposit Zálesí near Javorník in Rychlebské hory Mts. Acta Museae Moraviae, Science Geologie XC, 99-107. (in Czech).

GODOVIKOV A.A., FERYANCHICH F.A., 1960: The finding of the rare bismuth selenides - laitakarite in the SSSR. Geology and Geophysics 10, 19-26 (in Russian).

GRECULA P. Ed., 1995: Raw mineral deposits of the Slovak Ore Mountain, vol. 1., Geocomplex, Bratislava, 834 pp. (in Slovak with English summary).

HARUNA M., SATOH H., BANNO Y., KONO M., BUNNO M., 2002: Mineralogical and oxygen isotopic constraints on the origin of the contact-metamorphosed bedded manganese deposit at Nagasawa, Japan. Canadian Mineralogist 40, 1069-1089.

HURAi V., HARČOVÁ E., HURAIOVÁ M., OZdÍN D., PROCHASKA W., WIEGEROVÁ V., 2002: Origin of siderite veins in the Western Carpathians $-\mathrm{I}$. P-T-X- $-{ }^{813} \mathrm{C}-{ }^{-} 18 \mathrm{O}$ relations in ore-forming brines of the Rudňany deposits. Ore Geology Reviews 21, 1-2, 67-101. 
ILAVSKÝ J., 1954: Smolník - marginal localities, pyrite. Final Report and resources calculation. Unpublished manuscript, Spišská Nová Ves, 187 pp. (in Slovak).

JELEŇ S., 1994: Naumannite - the first selenide in the ores from the Štiavnica-Hodruša ore field. Mineralia Slovaca 26, 63-66 (in Slovak).

JELEŇ S., 2003: Petzite from the precious-metal mineralization of the Svätozár vein system, Banská Hodruša deposit. In: Mineralogy of the Bohemian Massive and the Western Carpathians Seminar Yearbook. 30-33 (in Slovak).

JELEŇ S., MAŤO L., KODĚRA P., KOVALENKER V.A., 2004: Se-Te mineralogy of Neogene epithermal deposits and occurrences of Slovakia. In: Gold-Silver-Telluride Deposits of the Golden Quadrilateral, South Apuseni Mts., Romania. Guidebook, International Field Workshop of IGCP-486, Alba Iulia, Romania, 31st August - 7th September 2004. IAGOD Guidebook Series 12, 230-231.

KALIČIAK M., ĎUĎA R., 1981: Time development and classification of the ore mineralization in the Zlatá Ban̆a ore district. Mineralia Slovaca 13, 1, 1-23. (in Slovak).

KALINAJ M., BEBEJ J., 1992: Mineralogical, petrological and geochemical study of the Au mineralization at the 14th level of the Rozália vein. Unpublished manuscript, GÚ SAV, Banská Bystrica, 138 pp. (in Slovak).

KATO A., 1959: Ikunolite, a new bismuth mineral from the Ikuno mine, Japan. Mineralogical Journal Japan 2 , 397-407.

LEXA J., ŠTOHL J., BRLAY A., MARSINA K., MIHÁliKOVÁ A., ROJKOVIČOVÁ L', ŽÁKOVÁ E., PANÁS̆EK A., ONAČILA D., 1989: Evaluation of the drilling hole B-2, BBR-1 and assumption and evaluation of the Banská Belá surroundings. Unpublished manuscript, Geofond, Bratislava, 124 pp. (in Slovak).

MARCOUXE., MOËLO Y., LEISTEL J.M., 1996: Bismuth and cobalt minerals as indicators of stringer zones to massive sulphide deposits, Iberian Pyrite Belt. Mineralium Deposita 31, 1-26.

MARKHAM N.L., (1962: Plumbian ikunolite from Kingsgate, New South Wales. American Mineralogist 47, 11-12.

MAŤO L., 1994: Minerals of the tetrahedrite-tennantite-goldfieldite solid solution from Kremnica. Mineralia Slovaca 26, 6, 433-445. (in Slovak).

MAŤO L', BEBEJ J., 1994: Evaluation of the Au mineralization from the 14th level of the Rozália mine, Banská Hodruša. A report from the research of the mineralization during the job Rozália vein Au-VP. Unpublished manuscript, Slovak mining company archive, Banská Hodruša, 158 pp. (in Slovak).

MAŤO L., HÁBER M., KNÉSL J., 1987: Occurrence of the Te minerals in the Kremnica ore district. Mineralia Slovaca 19, 5, 457-467. (in Slovak).

MAŤO L., ANDRÁŠ P., BITO A., 1990: Content of the tellurium in the mineralized structures of the $1^{\text {st }}$ vein system in the Kremnica ore field. Geologický Průzkum 32, 37-39. (in Slovak).

MAŤO L., KNÉSL J., ROJKOVIČOVÁ L'., 1996: Tellurides from the NW part of the Hodruša ore field, middle Slovak neovolcanites. Mineralia Slovaca 28, 4, 259-264. (in Slovak).

MOËLO Y., ROGER G., MAUREL-PALACIN D., MARCOUX E., LAROUSSI A., 1995: Chemistry of some $\mathrm{Pb}-(\mathrm{Cu}, \mathrm{Fe})-(\mathrm{Sb}, \mathrm{Bi})$ sulfosalts from France and Portugal. Implications for the crystal chemistry of lead sulfosalts in the $\mathrm{Cu}$-poor part of the $\mathrm{Pb}_{2} \mathrm{~S}_{2}-\mathrm{Cu}_{2} \mathrm{~S}_{-} \mathrm{Sb}_{2} \mathrm{~S}_{3}-\mathrm{Bi}_{2} \mathrm{~S}_{3}$ system. Mineralogy and Petrology 53, 229-250.

MOËLO Y., MAKOVICKY E., MOZGOVA N.N., JAMBOR J.L., COOK N., PRING A., PAAR W., NICKEL E.H., GRAESER S., KARUP-MØLLER S., BALIC-ŽUNIC T., MUMME G.W., VURRO F., TOPA D., BINDI L., BENTE K., SHIMIZU M., 2008: Sulfosalt systematics: a review. Report of the Sulfosalt Sub-committee of the IMA Commission on Ore Mineralogy. European Journal of Mineralogy 20, 7-46.

MUMME W.G., 1975: Junoite $\mathrm{Cu}_{2} \mathrm{~Pb}_{3} \mathrm{Bi}_{8}(\mathrm{~S}, \mathrm{Se})_{16}$, a new sulfosalt from Tennant Creek, Australia: Its crystal structure and relationship with other bismuth sulfosalts. American Mineralogist 60, 548-558.

NICKEL E.H., 1992: Solid solutions in mineral nomenclature. Canadian Mineralogist 30, 231-234.

ONAČILA D., ROJKOVIČOVÁ L., ŽÁKOVÁ E., REPČOK J., ELIÁŠ K., KALINAJ M., 1993: Epithermal vein mineralization of the Hodruša ore field. Unpublished manuscript, Geofond, Bratislava. 142 pp. (in Slovak).

PETEREC D., 1991: Chemistry and zonality of the Ni-Co mineralization in the Úhorná ore field. Mineralia Slovaca 23, 223-235 (in Slovak).

PETEREC D., 1996: Selenium and tellurium mineralization in the Smolník surrounding. Natura Carpatica XXXVII, 53-62 (in Slovak).

PIESTRZYŃSKI A., 1992: $\mathrm{Bi}_{4} \mathrm{Se}_{3}$ a new unnamed mineral from the Kupferschiefer, Polish Lowland: preliminary report. Mineralogia Polonica 23, 2, 35-42. 
PLOTINSKAYA O.YU., KOVALENKER V.A., SELTMANN R., STANLEY C.J., 2006: Te and Se mineralogy of the high-sulfidation Kochbulak and Kairagach epithermal gold telluride deposits (Kurama Ridge, Middle Tien Shan, Uzbekistan). Mineralogy and Petrology 87, 187-207.

PRINGLE G.J., THORPE R.I., 1980: Bohdanowiczite, junoite and laitakarite from the Kidd-Creek mine, Timmins, Ontario. Canadian Mineralogist 18, 3.

RADVANEC M., GRECULA P., ŽÁK K., 2004: Siderite mineralization of the Gemericum Superunit (Western Carpathians, Slovakia: review and a revised genetic model. Ore Geology Reviews 24, 267-298.

RAGAN M., 1989: Mineralogical, geochemical and paragenetic characteristic of the sulphide mineralization in the Hnúšt’a area (Veporic Unit). Unpublished PhD. Thesis Geofond, Bratislava 199 pp. (in Slovak).

RAGAN M., CAŇO F., 1991: First data about two new sulphosalts (CuPbSbBi and AgPbBiSb) with selenium from the talc deposit Hnúšt’a. Mineralia Slovaca 23, 368 (in Slovak).

ŘÍDKOŠIL T., SKÁLA R., JOHAN Z., ŠREIN V., 2001: Telluronevskite, $\mathrm{Bi}_{3} \mathrm{TeS}_{2}$, a new mineral. European Journal of Mineralogy 13, 177-185.

ROJKOVIČ I., NOVOTNÝ L., HÁBER M., 1993: Stratiform and vein U, Mo and Cu mineralization at Novoveská Huta area. Mineralium Deposita 28, 1, 58-65.

SEJKORA J., LITOCHLEB J., ČERNÝ P., OZDÍN D., 2004: Bi-Te mineral association from Župkov (Vtáčnik Mts, Slovak republic. Mineralia Slovaca 36, 303-315 (in Slovak).

SKÁLA R., ONDRUŠ P., VESELOVSKÝ F., TÁBORSKÝ Z., ĎUĎA R., 2007: Vihorlatite, $\mathrm{Bi}_{24} \mathrm{Se}_{17} \mathrm{Te}_{4}$, a new mineral of the tetradymite group from Vihorlat Mts., Slovakia. European Journal of Mineralogy 19, $255-265$.

STRUNZ H., 1963: Homeotypie $\mathrm{Bi}_{2} \mathrm{Se}_{2}-\mathrm{Bi}_{2} \mathrm{Se}_{3}-\mathrm{Bi}_{3} \mathrm{Se}_{4}-\mathrm{Bi}_{4} \mathrm{Se}_{5}$ usw. (Platynit, Ikunolith, Laitakarit). Neues Jahrbüch für Mineralogie - Monatshefte 154-157.

ŠTOHL J., HOJSTRIČOVÁ E., MIHOKOVÁ M., ROJKOVIČOVÁ L'., 1989: Base metal mineralization from Šobov. In: Abstracts yearbook from the Banský Studenec conference. Metalogenesy of the small intrusions in the Slovak neovolcanites, 19-20 (in Slovak)

VORMA A., 1959: Laitakarite, a new Bi-Se mineral in Orijarvi. Bulletin of Geology Commission of Finland 188, 1-10 (in Finnish).

VURRO F., GARAVELli A., GARBARINO C., MOËLO Y., BORODAYEV Y.S., 1999: Rare sulphosalts from Vulcano, Aeolian Islands, Italy. II Mozgovaite, $\mathrm{PbBi}_{4}(\mathrm{~S}, \mathrm{Se})_{7}$. Canadian Mineralogist 37, 1499-1506.

WAGNER T., JONSSON E., 2001: Mineralogy of sulfosalt-rich vein-type ores, Boliden massive sulfide deposit, Skellefte district, Northern Sweden. Canadian Mineralogist 39, 855-872.

ZAVYALOV E.H., BEGIZOV V.D., TSCHVILEVA T.N., 1983: New data about laitakarite. Zapiski Vsesoyuznoye Mineralogicheskogo Obschestva 2, 185-192, (in Russian).

ZAKRZEWSKI M., MAKOVICKY E., 1986: Izoklakeite from Vena, Sweden, and the kobellite homologous series. Canadian Mineralogist 24, 7-18.

ZEPHAROVICH V., 1859: Mineralogisches Lexicon für das Kaisserthum Österreich. I, Bd. Wien, Wilhelm Braumüller, $627 \mathrm{pp}$.

ZEPHAROVICH V., 1873: Mineralogisches Lexicon für das Kaisserthum Österreich. II, Bd. Wien, Wilhelm Braumüller, 627 pp. 